\title{
Neutrophils and interferon-a-producing cells: who produces interferon in lupus?
}

\author{
Patrice Decker*
}

\begin{abstract}
Interferon-a plays a crucial role in the pathogenesis of systemic lupus erythematosus. Nevertheless, the different human cell types producing this cytokine as well as the stimuli inducing its production have not been completely characterized. So far, a subpopulation of dendritic cells activated by immune complexes has been identified as major producers of interferon-a in patients with lupus. However, those cells represent a minor population and some studies have reported the secretion of interferon-a by other cells. On the other hand, more than $50 \%$ of blood leukocytes are neutrophils and their functions are still not fully understood. Recent data suggest that neutrophils, though usually not considered interferon-a-producing cells, may represent an unexpected source of this cytokine in response to some lupus stimuli.
\end{abstract}

Serum interferon (IFN)- $\alpha$ concentrations are elevated in patients with systemic lupus erythematosus (SLE) [1] and contribute to the break of peripheral tolerance by sustaining the differentiation of myeloid dendritic cells [2]. IFN- $\alpha$ actually increases the differentiation of monocytes into dendritic cells that present antigens from dying cells to $\mathrm{CD} 4^{+}$lymphocytes, resulting in their proliferation. The involvement of IFN- $\alpha$ in SLE development is further supported by the IFN-inducible gene expression signature that characterizes a clinical subset of patients with SLE and more severe disease (for example, damage of the kidneys or the central nervous system) [3]. Plasmacytoid dendritic cells (PDCs) have been suggested to be the main cells producing IFN- $\alpha$ [4], and an inducer of IFN- $\alpha$ has been identified in the circulation of patients with SLE [5]. Currently, PDCs activated by DNA- and RNAcontaining immune complexes are believed to be the main source of IFN- $\alpha$ in SLE upon triggering of Toll-like

*Correspondence: patrice.decker@univ-paris13.fr

EA4222, Li2P, University of Paris 13, 74 rue Marcel Cachin, 93017 Bobigny, France receptor (TLR) 9 and TLR7, respectively, in cooperation with CD32 [6-8]. Nevertheless, PDC depletion experiments suggest that other cell types produce IFN- $\alpha$ in SLE [2] and type I IFN production occurs independently of Fc $\gamma$ receptors in a lupus mouse model [9], indicating that uptake of immune complexes is not required. In a different lupus mouse model, the double-stranded RNA analog poly I:C was shown to induce IFN- $\alpha$ production in spleen monocytes [10], confirming that - depending on the stimulus - cells other than PDCs may produce IFN- $\alpha$ independently of the presence of immune complexes.

Interestingly, Fairhurst and colleagues [11] recently showed that type I IFNs are produced by resident renal cells, suggesting that locally produced IFN- $\alpha$ may promote glomerulonephritis development. Moreover, this mechanism seems to involve the recruitment of neutrophils (polymorphonuclear leukocytes, or PMNs). In agreement with those results, granulocytes are activated in active SLE as suggested by the overexpression of granulopoiesis-related genes, known as the granulopoiesis signature [12]. This microarray analysis performed on blood cells suggests that granulocytes are involved in SLE pathogenesis. Moreover, PMNs are about 200 times more abundant than PDCs in the blood and are the first cells recruited at sites of inflammation. PMNs play a central role in host defense and, once activated, produce proinflammatory cytokines and reactive species. However, upon inappropriate activation, PMN-derived products may induce tissue damage. PMNs express TLRs 1 to 10 (except TLR3) and link innate and adaptive immunity by influencing, for example, dendritic cells. Importantly, PMNs are capable of producing IFN- $\alpha$ in response to some stimuli [13]. Normal and lupus PMNs, however, were not compared and only granulocyte colony-stimulating factor (G-CSF), in contrast to lipopolysaccharide (LPS) or $\mathrm{N}$-formyl-methionine-leucine-phenylalanine (fMLP), was shown to induce IFN- $\alpha$ mRNA transcripts. A recent study confirmed the latter observation by using PMNs isolated from patients with SLE and described the induction of type I IFN upon activation with G-CSF, phorbol 12-myristate 13-acetate (PMA), or transfected poly I:C, although the natural lupus stimulus and the mechanism involved were not identified [14]. The 
aforesaid cells represent a subset of proinflammatory PMNs secreting increased levels of several cytokines, such as tumor necrosis factor (TNF) and IFN- $\gamma$ (upon activation), and may induce vascular damage. Those cells are low-density PMNs and represent an abnormal subset of neutrophils present in peripheral blood mononuclear cell (PBMC) preparations from patients with lupus. Lowdensity PMNs present features of both immature and activated PMNs and have a decreased phagocytic potential, but it is still unknown whether they represent a distinct cell population. It should be noted that another study has shown that human PMNs isolated from healthy donors also produce IFN- $\beta$ mRNA upon stimulation with transfected poly I:C [15], although IFN- $\alpha / \beta$ secretion was not detected. Likewise, mouse PMNs infected with encephalomyocarditis virus express IFN- $\beta$ mRNA, a mechanism partially dependent on the cytoplasmic RNA helicase MDA5. In regard to IFN- $\alpha$, we could show that PMNs activated by chromatin, a major autoantigen in SLE, produced IFN- $\alpha$ in an immune complex-independent manner whereas non-stimulated PMNs did not (Dennis Lindau and colleagues, University of Paris 13, France, manuscript submitted). Mono-nucleosomes were particularly efficient in inducing PMN activation. In contrast to the findings of Denny and colleagues [14], IFN- $\alpha$ production was detected in steady-state PMNs and with PMNs isolated from both patients with SLE and healthy donors, suggesting that a key event is the presence of increased concentrations of circulating nucleosomes, a situation especially common in vivo in patients with SLE. Together with our previous results showing that free chromatin stimulates PMNs [16] independently of TLR9 [17], leading to interleukin (IL)-8, IL-6, and TNF secretion, CD11b upregulation, and increased phagocytic activity, all of those studies reveal an unsuspected role for PMNs in SLE pathogenesis. Nevertheless, further studies will be needed to identify the pathway elicited. A cellular cross-talk might be required to efficiently trigger IFN- $\alpha$ secretion by PMNs. Owing to their proinflammatory activity $[18,19]$, platelets might be involved. Indeed, platelets activated by immune complexes were recently shown to potentiate IFN- $\alpha$ secretion by PDCs in SLE through a CD154-CD40 interaction [20]. Depending on the stimulus, activated PMNs may secrete IFN- $\alpha$ early during the lupus disease, before immune complexes are produced, bypassing the classical mechanism requiring the induction of autoantibodies and the formation of immune complexes activating PDCs. Thus, two complementary pathways might be involved in IFN- $\alpha$ induction in SLE.

\section{Conclusions}

Because IFN- $\alpha$ secretion is a key pathogenic event in SLE, the characterization of the cellular sources and the lupus stimuli represents a crucial step for the development of new therapeutic strategies aiming at controlling IFN- $\alpha$ secretion, especially at an early stage of the disease. Because they are abundant and recruited in inflamed tissues, activated PMNs may represent a new therapeutic target. Finally, future studies will be necessary to determine whether neutrophil extracellular traps (NETs) are involved in the induction of IFN- $\alpha$ production by PMNs and reciprocally whether circulating chromatin triggers the formation of NETs. Indeed, NETs are structures formed by activated PMNs and contain chromatin [21]. Because they form fibers that bind and kill bacteria, NETs represent a type of innate response. In particular, mature SLE PMNs have been shown very recently to release immunogenic NETs upon exposure to autoantibodies, leading to an activation-induced cell death named NETosis, and those lupus NETs trigger the production of IFN- $\alpha$ by PDCs in a TLR9-dependent manner [22,23]. Interestingly, this mechanism occurs in IFN- $\alpha$-primed PMNs, implying that IFN- $\alpha$ had already been induced. Collectively, the data suggest that PMN-derived or PMNinduced IFN- $\alpha$ or both might have been underestimated.

\section{Abbreviations}

G-CSF, granulocyte colony-stimulating factor; fMLP, N-formyl-methionineleucine-phenylalanine; IFN, interferon; IL, interleukin; LPS, lipopolysaccharide; NET, neutrophil extracellular trap; PBMC, peripheral blood mononuclear cell; PDC, plasmacytoid dendritic cell; PMA, phorbol 12-myristate 13-acetate; PMN, polymorphonuclear leukocyte; SLE, systemic lupus erythematosus; TLR, Toll-like receptor; TNF, tumor necrosis factor.

\section{Competing interests}

The author declares that he has no competing interests.

\section{Authors' information}

Until August 2010, the author was affiliated with the Department of Immunology, Institute for Cell Biology, University of Tübingen (Tübingen, Germany). In September 2010, he moved to the University of Paris 13, France.

\section{Acknowledgments}

This work was supported by grants from the German Research Foundation (DFG, DE 879/1-1 and DE 879/1-2), the University of Tübingen (IZKF-Nachwuchsgruppe, 1604-0-0 and 1604-0-1), and the Fritz-Thyssen Foundation and by the University of Paris 13 and INSERM. I thank Dennis Lindau (University of Nijmegen, The Netherlands) and Marie-Christophe Boissier (University of Paris 13) for critical reading of the manuscript.

Published: 6 July 2011

\section{References}

1. Preble OT, Black RJ, Friedman RM, Klippel JH, Vilcek J: Systemic lupus erythematosus: presence in human serum of an unusual acid-labile leukocyte interferon. Science 1982, 216:429-431.

2. Blanco P, Palucka AK, Gill M, Pascual V, Banchereau J: Induction of dendritic cell differentiation by IFN-alpha in systemic lupus erythematosus. Science 2001, 294:1540-1543.

3. Baechler EC, Batliwalla FM, Karypis G, Gaffney PM, Ortmann WA, Espe KJ, Shark KB, Grande WJ, Hughes KM, Kapur V, Gregersen PK, Behrens TW: Interferon-inducible gene expression signature in peripheral blood cells of patients with severe lupus. Proc Natl Acad Sci U S A 2003, 100:2610-2615.

4. Siegal FP, Kadowaki N, Shodell M, Fitzgerald-Bocarsly PA, Shah K, Ho S, Antonenko S, Liu YJ: The nature of the principal type 1 interferonproducing cells in human blood. Science 1999, 284:1835-1837.

5. Vallin H, Blomberg S, Alm GV, Cederblad B, Ronnblom L: Patients with systemic lupus erythematosus (SLE) have a circulating inducer of 
interferon-alpha (IFN-alpha) production acting on leucocytes resembling immature dendritic cells. Clin Exp Immunol 1999, 115:196-202.

6. Barrat FJ, Meeker T, Gregorio J, Chan JH, Uematsu S, Akira S, Chang B, Duramad O, Coffman RL: Nucleic acids of mammalian origin can act as endogenous ligands for Toll-like receptors and may promote systemic lupus erythematosus. J Exp Med 2005, 202:1131-1139.

7. Means TK, Latz E, Hayashi F, Murali MR, Golenbock DT, Luster AD: Human lupus autoantibody-DNA complexes activate DCs through cooperation of CD32 and TLR9. J Clin Invest 2005, 115:407-417.

8. Vollmer J, Tluk S, Schmitz C, Hamm S, Jurk M, Forsbach A, Akira S, Kelly KM, Reeves WH, Bauer S, Krieg AM: Immune stimulation mediated by autoantigen binding sites within small nuclear RNAs involves Toll-like receptors 7 and 8. J Exp Med 2005, 202:1575-1585.

9. Lee PY, Kumagai Y, Li Y, Takeuchi O, Yoshida H, Weinstein J, Kellner ES, Nacionales D, Barker T, Kelly-Scumpia K, van RN, Kumar H, Kawai T, Satoh M, Akira S, Reeves WH: TLR7-dependent and FcgammaR-independent production of type I interferon in experimental mouse lupus. J Exp Med 2008, 205:2995-3006.

10. Patole PS, Grone HJ, Segerer S, Ciubar R, Belemezova E, Henger A, Kretzler M Schlondorff D, Anders HJ: Viral double-stranded RNA aggravates lupus nephritis through Toll-like receptor 3 on glomerular mesangial cells and antigen-presenting cells. J Am Soc Nephrol 2005, 16:1326-1338.

11. Fairhurst AM, Xie C, Fu Y, Wang A, Boudreaux C, Zhou XJ, Cibotti R, Coyle A, Connolly JE, Wakeland EK, Mohan C: Type I interferons produced by resident renal cells may promote end-organ disease in autoantibodymediated glomerulonephritis. J Immuno/ 2009, 183:6831-6838.

12. Bennett L, Palucka AK, Arce E, Cantrell V, Borvak J, Banchereau J, Pascual V: Interferon and granulopoiesis signatures in systemic lupus erythematosus blood. J Exp Med 2003, 197:711-723.

13. Shirafuji N, Matsuda S, Ogura H, Tani K, Kodo H, Ozawa K, Nagata S, Asano S, Takaku F: Granulocyte colony-stimulating factor stimulates human mature neutrophilic granulocytes to produce interferon-alpha. Blood 1990, 75:17-19.

14. Denny MF, Yalavarthi S, Zhao W, Thacker SG, Anderson M, Sandy AR, McCune WJ, Kaplan MJ: A distinct subset of proinflammatory neutrophils isolated from patients with systemic lupus erythematosus induces vascular damage and synthesizes type I IFNs. J Immunol 2010, 184:3284-3297.

15. Tamassia N, Le M, V, Rossato M, Donini M, McCartney S, Calzetti F, Colonna M, Bazzoni F, Cassatella MA: Activation of an immunoregulatory and antiviral gene expression program in poly(l:C)-transfected human neutrophils. J Immunol 2008, 181:6563-6573.

16. Rönnefarth VM, Erbacher Al, Lamkemeyer T, Madlung J, Nordheim A, Rammensee HG, Decker P: TLR2/TLR4-independent neutrophil activation and recruitment upon endocytosis of nucleosomes reveals a new pathway of innate immunity in systemic lupus erythematosus. J Immunol 2006, 177:7740-7749.

17. Lindau D, Ronnefarth V, Erbacher A, Rammensee HG, Decker P: Nucleosomeinduced neutrophil activation occurs independently of TLR9 and endosomal acidification: implications for systemic lupus erythematosus. Eur J Immunol 2011, 41:669-681.

18. Henn V, Slupsky JR, Grafe M, Anagnostopoulos I, Forster R, Muller-Berghaus G Kroczek RA: CD40 ligand on activated platelets triggers an inflammatory reaction of endothelial cells. Nature 1998, 391:591-594.

19. Elzey BD, Tian J, Jensen RJ, Swanson AK, Lees JR, Lentz SR, Stein CS, Nieswandt B, Wang Y, Davidson BL, Ratliff TL: Platelet-mediated modulation of adaptive immunity. A communication link between innate and adaptive immune compartments. Immunity 2003, 19:9-19.

20. Duffau P, Seneschal J, Nicco C, Richez C, Lazaro E, Douchet I, Bordes C, Viallard JF, Goulvestre C, Pellegrin JL, Weil B, Moreau JF, Batteux F, Blanco P: Platelet CD154 potentiates interferon-alpha secretion by plasmacytoid dendritic cells in systemic lupus erythematosus. Sci Trans/ Med 2010, 2:47ra63.

21. Brinkmann V, Reichard U, Goosmann C, Fauler B, Uhlemann Y, Weiss DS, Weinrauch Y, Zychlinsky A: Neutrophil extracellular traps kill bacteria. Science 2004, 303:1532-1535.

22. Garcia-Romo GS, Caielli S, Vega B, Connolly J, Allantaz F, Xu Z, Punaro M, Baisch J, Guiducci C, Coffman RL, Barrat FJ, Banchereau J, Pascual V: Netting neutrophils are major inducers of type I IFN production in pediatric systemic lupus erythematosus. Sci Trans/ Med 2011, 3:73ra20.

23. Lande R, Ganguly D, Facchinetti V, Frasca L, Conrad C, Gregorio J, Meller S, Chamilos G, Sebasigari R, Riccieri V, Bassett R, Amuro H, Fukuhara S, Ito T, Liu YJ, Gilliet M: Neutrophils activate plasmacytoid dendritic cells by releasing self-DNA-peptide complexes in systemic lupus erythematosus. Sci Trans/ Med 2011, 3:73ra19.

doi:10.1186/ar3345

Cite this article as: Decker P: Neutrophils and interferon- $\alpha$-producing cells: who produces interferon in lupus? Arthritis Research \& Therapy 2011, 13:1 18. 